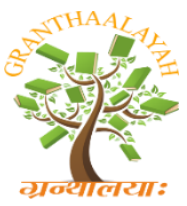

\author{
INTERNATIONAL JOURNAL OF RESEARCH \\ GRANTHAALAYAH \\ A knowledge Repository
}

Social

\title{
SOME SELECTED FACTORS AFFECTING EATING BEHAVIOR OF ADOLESCENT: IMPLICATION FOR HOME ECONOMICS
}

\author{
Uwameiye B.E. ${ }^{* 1}$ \\ ${ }^{* 1}$ Department of Vocational and Technical Education, Ambrose Alli University, EK poma. Edo \\ State, Nigeria
}

\begin{abstract}
This research identified some selected factors affecting the eating behavior of adolescent in Esan West Local Government Area. Four questions and four null hypotheses guided the study. A total of 679 students were utilized. A 30-item questionnaire was the instrument for gathering the data. Mean, standard deviations answered the research questions, while the t-test was utilized for testing the null hypotheses at.05 level of significance. Findings revealed among others that the respondents have poor eating behavior such as skipping of breakfast among urban and rural respondents $(1.06,1.02)$, low consumption of fruits and vegetable, $(3.01,3.20)$ Consume fried foods daily $(3.33,2.56)$. Low intake of carbohydrates among the urban respondents $(2.55)$ then, the rural respondents (3.22), regular consumption of sweets, biscuits, snacks, soda and sweetened drinks daily among respondents. $(3.05,2.60)$. Other findings are that respondents agreed that all the maternal, environmental and media factors affect the eating behavior of the adolescent. The result also indicates that hypothesis one had significant differences in items 3,5,6\&7. Which mean that the stated null hypothesis at.05 level of significance is rejected for those items. The results in items $1,2,4,8,9 \& 10$ indicated there is no significant difference in their mean responses, therefore the null hypothesis of no significance difference is retained for those items. In the last three hypotheses all the items had t calculated less than t-table value of 1.96 at.05 level of significance. Thus, the hypotheses of no significant difference were retained in the three hypotheses. The study recommended among others that: Parents should be advised to guide and monitor their children in the use of the media, by occupying their children with other physical activities to reduce television viewing, video games and the use of computer, so as to guide against the acquisition of wrong nutrition information that can lead to poor eating behavior.
\end{abstract}

Keywords: Eating Behavior; Changes; Nutritional Challenges; Family Life; Home Economics.

Cite This Article: Uwameiye B.E.. (2018). "SOME SELECTED FACTORS AFFECTING EATING BEHAVIOR OF ADOLESCENT: IMPLICATION FOR HOME ECONOMICS." International Journal of Research - Granthaalayah, 6(12), 1-11. https://doi.org/10.29121/granthaalayah.v6.i12.2018.1069. 


\section{Introduction}

Adolescence is a period in the life of a growing child which span between the ages of 10 to 19 years. According to ${ }^{\mathbf{1}}$ it is a time when the child experiences massive biological, mental and physiological changes. In addition, ${ }^{2}$ sees it as a time when the child gains an astronomical physical increase. Moreover, it is a midway between childhood and adulthood in the life cycle; therefore a lot of these bodily changes take place for the transition to happen. To this end, these sudden bodily changes, noticed by the adolescent gives them the impression that they have become adults. Consequently, they are endeared towards the formation of habits to cope with the changes.

One of such unique characteristics of the adolescent is craving for freedom from parental control or any constituted authority; in the process acquire certain behavior that may be detrimental to his wellbeing. Worthy of mention as opined by ${ }^{\mathbf{3}}$ is the behavior of inadequate intake of fruits, vegetable and dairy foods. Eating behavior is easily influenced by several factors and the adolescent begin a young adult is easily exposed to these factors. It is also a statement of fact that unhealthy weight control practices and overweight status are common during the adolescent period. Therefore, this liberty period can also provide a liberal chance for the adolescent to acquire a healthy eating behavior to meet up with the nutritional challenges, for which ever behavior the child forms at this stage may continue to adulthood and even into future generation.

Healthy eating is a fundamental aspect of life. Life cannot be efficiently sustained when the body is not sufficiently fed with the essential nutrient in its right quantity. In nature, good nutrition guide against diseases and person's dietary echelon may be directly or indirectly determined by the quality and quantity of food he eats. According to ${ }^{4}$ eating behavior is a multifaceted interaction of emotional and hereditary factors that control food choice and intake. It means the eating routine including food choices people make daily which may be habitual or lopsided. It could be arranged as breakfast, lunch or dinner. Furthermore, it involves the everyday mealtime composition as well as intakes between meals (snacks). Therefore, eating behavior are habits created or formed by the individual in different stages in life, In early childhood, mothers and care givers help to determine baby's food behavior hence, ${ }^{\mathbf{5}}$ acknowledged that an infant eating behavior is shaped by parents in accordance with their view of what constitute a healthy baby. At adolescence the challenge lies in the various factors which may be increasing their motivation or increasing the barriers towards healthy eating.

One of such is the maternal factor. In most homes mothers purchase and plan family menu thus, has the responsibility of considering the likes and dislikes of every child. She gives food portions to the children according to their sex, age and needs, thus, mothers are a major role player in the nourishment of the family. She also selects her meals in accordance with the family's culture as well as other factors. To this end, ${ }^{\mathbf{6}}$ reported that mother's concern for nourishment was fully associated with children's fruits and vegetables intake. Which means mother's apprehension for good health may be capable of influencing the food choice and dietary habit of their children. Besides, mothers make sure the family is united by sharing meals together in the family and children learn eating behavior from watching and participating in the eating pattern of others, as children learn by imitation or by copying the actions of people around them. Consequently, eating behavior is gradually developed from childhood through adolescent to adulthood. This habit of eating together may be able to influence the adolescent eating behavior, in all of these; the child would want to emulate the eating behavior of the family. Furthermore, ${ }^{7}$ opined that maternal 
parenting style influences a child's overall diet quality. This involve the mother utilizing parenting strategies such disciplinary measures, good communication styles, monitoring and control to set limits on food behavior for their children.

Another factor is the home environment. Home environment is the place of abode, which literature had as important context affecting eating pattern among children ${ }^{8}$ It is the child's primary background the place where he or she first acquires his unofficial education (informal). In the home, the child interacts with his relatives. Prominent among them are the parents. They play very important role in influencing the eating behavior of their offspring. This they do by providing food they perceive to be necessary thereby playing the role of a model on the ideal eating behavior. Furthermore, household environmental factors such as the neighborhood where the family resides may affect the adolescents eating behavior. The adolescent is a small adult who would want to explore his environment; home environment will determine his accessibility to eateries, canteens and neighborhood shops. An urban environment exposes the adolescents to all kinds of eateries while rural environment are limited or may not have any. Moreover, ${ }^{\mathbf{3}}$ identified food availability in an environment to be an important background influencing the eating pattern and weight gain status among families. Neighborhood local fruit and vegetable market, retail shops, fast food restaurant and convenience stores in rural communities may be a contributory factor to the eating pattern of a family in that neighborhood. Social environment involves the interaction with family and friends. According to ${ }^{9}$ when food is eaten in group, persons have a propensity to learn the eating behavior of others. This style of behavior is known as role modeling. Likewise, certain foods are unavailable resulting to decreased choice and intake ${ }^{\mathbf{1 0}}$

Lastly is the media factor involving television viewing, listening to radio programme, use of social the print media. All these are medium of attractive advertisements. They utilize striking techniques to get their audience interested or involved. For this and other reasons children of various ages spend most hours of the day in the use of these gadgets. The television is a channel for several adverts; prominent is foods advert and if the adolescent is not guided may affect her food choice or shape their eating behavior. Television viewing is a form of distraction while eating. When People gaze at the television without paying attention to the food being eating, such may eat more than someone who is well focused while eating. Bloggers and other social media users send colorful recipes of dishes on social media. These they present in form of photos, videos, slides, info graphic. They are showcased in a calculated manner for they are usually short, attractive and eye catching. In addition, the different social media present some models in advertisement, and the adolescent sees these as the ideal figure, therefore would see such as their role model. In an attempt to attain such figure would indulge in some bad food preferences that will be detrimental to their health. Recently the social media have been saturated with nutrition information which is capable of leading or misleading the adolescent towards a eating behavior. ${ }^{\mathbf{1 1}}$ postulated that advertising junk foods on children's television channels is a foremost source of children's intake of unwholesome diet.

\section{Methods}

This study utilized the descriptive survey research design to investigate some selected factors influencing food behavior among adolescent in Esan West Local Government of Edo State. The population for the study consisted of all the 698 Senior Secondary School 11 students in Esan West 
Local Government Area of Edo state. Esan West is made up of Urban and Rural Areas. The Urban areas are Eguare, Emaudo, Ihumudumu and Idumebo, while the rural areas are Ogwa, Ujogba, Egoro, Idoa and Ukhun.

The sample for this study was made up of the entire population of 698 adolescents between the ages of 14-19 years. This consisted of 402 urban and 296 rural adolescents. The 16 public schools were grouped into two, Urban and Rural areas, depending on their location. The ages of the adolescent were obtained from the school records. The instrument used was a structured questionnaire. It was titled "Some Selected factors Affecting Eating Behavior Questionnaire" (SSFAEBAQ) the items were based on the information gathered from the review of related literature. The instrument used a four point scale for rating the response options: Strongly Agree (4), Agree (3), Disagree (2) and Strongly Disagree 1. The instrument was face validated by three experts from Home Economics Department in Ambrose Alli University, Ekpoma. The reliability of the instrument was established using splint half reliability coefficient for testing the reliability of the instrument. For SSFAEBAQ, 30 adolescent in schools from neighboring local government schools that were not part of this study were used. The questions were split into two halves and the reliability coefficient was computed using spearman Rho to obtain reliability of 0.76 . The researcher and three research assistants administered the instrument, 689 were administered; 679 were retrieved which is $98.5 \%$ return rate.

The mean and standard deviation were utilized to analyze the research questions and the t-test statistics for the hypothesis at 0.05 level of significance. The mean value of (4) point response is 2.50. Therefore, any item below 2.5 is not affecting eating behavior of the adolescent. The hypothesis was accepted if the calculated t-value was less than the tabulated t-value of 1.90 as having no significant difference between the responses for the two groups of respondents. The alternative occurred if the calculated t-value was greater than the tabulated t-value of 1.90 .

\section{Results}

Research Question 1: What is the perception of students on the eating behavior of adolescents in Esan West Local Government Area?

Hypothesis 1: There is no significant difference between the perception of urban and rural students on the eating behavior of students in Esan West Local Government Area.

Table 1: Mean Response of Respondents on the Perception of Urban and Rural Students on the Eating Behavior of adolescents in Esan West Local Government Area.

\begin{tabular}{|l|l|l|l|l|l|l|l|}
\hline S/n. & Items & $\begin{array}{l}\mathbf{X}_{1} \\
\text { (urban) }\end{array}$ & $\mathbf{S D}_{1}$ & $\begin{array}{l}\mathbf{X}_{2} \\
\text { (rural) }\end{array}$ & $\mathbf{S D}_{2}$ & $\begin{array}{l}\text { t- } \\
\text { calt }\end{array}$ & Remarks \\
\hline 1. & $\begin{array}{l}\text { Always take breakfast before leaving } \\
\text { for school }\end{array}$ & 1.06 & 1.05 & 1.02 & 0.048 & 0.048 & $\mathrm{~N} / \mathrm{S}$ \\
\hline 2. & $\begin{array}{l}\text { Ask for more helpings when eating } \\
\text { foods at home }\end{array}$ & 2.88 & 0.07 & 3.01 & 0.146 & 0.146 & $\mathrm{~N} / \mathrm{S}$ \\
\hline 3. & $\begin{array}{l}\text { Weekly consumption of vegetables is } \\
\text { less than three times }\end{array}$ & 3.01 & 1.03 & 1.04 & 3.20 & 3.20 & $\mathrm{~S}$ \\
\hline 4. & Fried food is part of my meals daily & 3.33 & 1.06 & 2.56 & 0.205 & 0.205 & $\mathrm{~N} / \mathrm{S}$ \\
\hline
\end{tabular}




\begin{tabular}{|l|l|l|l|l|l|l|l|}
\hline 5. & $\begin{array}{l}\text { Consume one of these daily indomie, } \\
\text { spaghetti and macaroni daily. }\end{array}$ & 3.58 & 0.79 & 2.02 & 4.101 & 4.101 & $\mathrm{~S}$ \\
\hline 6. & $\begin{array}{l}\text { Type of food consume is more of } \\
\text { these rice, garri, akpu and yam. }\end{array}$ & 2.55 & 0.66 & 3.22 & 3.220 & 3.220 & $\mathrm{~S}$ \\
\hline 7. & $\begin{array}{l}\text { Type of food consumed is more of } \\
\text { meat, eggs, fish and chicken. }\end{array}$ & 3.48 & 1.03 & 2.03 & 3.040 & 3.040 & $\mathrm{~S}$ \\
\hline 8. & $\begin{array}{l}\text { Eat one or more of the following daily } \\
\text { sweets, biscuits, cakes. }\end{array}$ & 3.81 & 1.02 & 3.06 & 0.205 & 0.205 & $\mathrm{~N} / \mathrm{S}$ \\
\hline 9. & $\begin{array}{l}\text { Mid day snacks is meat pie, egg roll, } \\
\text { chin chin, biscuit }\end{array}$ & 3.80 & 0.56 & 3.08 & 0.205 & 0.205 & $\mathrm{~N} / \mathrm{S}$ \\
\hline 10. & $\begin{array}{l}\text { Sweetened drinks such as juice Coke, } \\
\text { fanta or soda is part of my daily snack. }\end{array}$ & 3.05 & 1.60 & 2.60 & 0.211 & 0.211 & $\mathrm{~N} / \mathrm{S}$ \\
\hline
\end{tabular}

Key, $\bar{X}_{1}$ - urban respondent $\bar{X}_{2}$ - rural respondents $N=679, n_{1}=400$ and $n_{2}=279$. N/S = Not significant $=S=$ Significant

The data presented in table 1 indicates that urban respondents agree that items 2-10 are their eating behavior while rural respondents agree that items $2,4,6,8,9 \& 10$ are the rural respondents eating behavior, their mean is above the cutoff point of 2.5. This indicates that all these are the eating behavior practiced by respondents. This table also reveals that there were significant difference in items $3,5,6 \& 7$. Signifying that, the null hypothesis of no significance difference at .05 level of significance is rejected for those items. The results in items $1,2,4,8,9 \& 10$ indicated there is no significant difference in their mean responses, therefore the null hypothesis of no significance difference is retained for those items.

Research Question 2: What is the perception of students on the maternal factors affecting the eating behavior of adolescents in Esan West Local Government Area?

Hypothesis 2: There is no significant difference between the perception of urban and rural adolescent on the maternal factors affecting the eating behavior of adolescent in Esan West Local Government of Area.

Table 2: Mean and t-test of Responses of Urban and Rural Adolescent on Maternal Factors affecting the eating Behavior of Adolescent.

\begin{tabular}{|l|l|c|c|c|c|l|l|}
\hline S/n. & Items & $\overline{\mathbf{X}}_{\mathbf{1}}$ & $\mathbf{S D}_{\mathbf{1}}$ & $\mathbf{X}_{\mathbf{2}}$ & $\mathbf{D}_{\mathbf{2}}$ & t-cal & Remarks \\
\hline 1. & $\begin{array}{l}\text { My mother plan and prepares the home } \\
\text { meals. }\end{array}$ & 3.06 & 0.44 & 3.02 & 0.61 & 0.771 & $\mathrm{~N} / \mathrm{S}$ \\
\hline 2. & $\begin{array}{l}\text { My mother make sure I consume my } \\
\text { meals }\end{array}$ & 3.13 & 0.60 & 3.05 & 0.58 & 0.766 & $\mathrm{~N} / \mathrm{S}$ \\
\hline 3. & $\begin{array}{l}\text { My mother include fruits and vegetables } \\
\text { in the preparation of the family meals }\end{array}$ & 3.03 & 0.50 & 3.18 & 0.61 & 0.119 & $\mathrm{~N} / \mathrm{S}$ \\
\hline 4. & $\begin{array}{l}\text { My mother serves us meals accordin g to } \\
\text { sex and nutritional needs. }\end{array}$ & 3.60 & 0.66 & 3.06 & 0.67 & 0.22 & $\mathrm{~N} / \mathrm{S}$ \\
\hline 5. & $\begin{array}{l}\text { My mother is concerned about the type of } \\
\text { food we consume daily. }\end{array}$ & 3.14 & 0.45 & 3.02 & 0.88 & 0.62 & $\mathrm{~N} / \mathrm{S}$ \\
\hline 6. & $\begin{array}{l}\text { My mother is always concerned about our } \\
\text { food habit }\end{array}$ & 1.04 & 0.74 & 3.66 & 0.72 & 0.32 & $\mathrm{~N} / \mathrm{S}$ \\
\hline
\end{tabular}




\begin{tabular}{|l|l|l|l|l|l|l|l|}
\hline 7. & The meals my mother prepares is tastier & 3.92 & 0.89 & 3.03 & 0.65 & 0.28 & $\mathrm{~N} / \mathrm{S}$ \\
\hline 8. & $\begin{array}{l}\text { I eat more when my mother prepares } \\
\text { meals. }\end{array}$ & 3.60 & 0.88 & 3.02 & 0.65 & 0.62 & $\mathrm{~N} / \mathrm{S}$ \\
\hline 9. & $\begin{array}{l}\text { My mother teaches us about good eating } \\
\text { habits. }\end{array}$ & 3.40 & 0.99 & 3.20 & 0.74 & 0.99 & $\mathrm{~N} / \mathrm{S}$ \\
\hline 10. & $\begin{array}{l}\text { My mother disciplines us if we refuse to } \\
\text { consume our meals }\end{array}$ & 3.70 & 0.88 & 3.60 & 0.68 & 0.22 & $\mathrm{~N} / \mathrm{S}$ \\
\hline
\end{tabular}

Key, $\bar{X}_{1}$ - urban respondent $\bar{X}_{2}$ - rural respondents $N=679, n_{1}=400$ and $n_{2}=279$. N/S = Not significant $=S=$ Significant

Table 2: Indicates that all the respondents agreed with all the items as maternal factors affecting the eating behavior of the adolescent. All the mean scores were above the cutoff of 2.50. The standard deviation of the maternal factors items ranged from 0.44 that to 0.99 . This shows that the respondents were close to one another in their opinion. The result also indicates that all the items had $t$ calculated less than t-table value of 1.96 at .05 level of significant. Therefore, the hypothesis of significant difference between ratings of the respondents upheld.

Research Question 3: What is the perception of students on the home environment factors affecting the eating behavior of adolescents in Esan West Local Government Area?

Hypothesis 3: There is no significant difference between the responses of Urban and Rural adolescent on the home environment factors affecting the eating behavior of the adolescent.

Table 3: Mean and t-test of Responses of Urban and Rural Adolescent on Home Environment factors affecting Adolescent Eating Behavior of Adolescents in Esan West Local Government Area.

\begin{tabular}{|l|l|l|l|l|l|l|l|}
\hline S/n. & Items & $\begin{array}{l}\mathbf{X}_{1} \\
(\mathbf{u r b a n})\end{array}$ & $\mathbf{S D}_{1}$ & $\begin{array}{l}\mathbf{X}_{2} \\
\text { (rural) }\end{array}$ & $\mathbf{S D}_{2}$ & $\begin{array}{l}\text { t- } \\
\text { cal }\end{array}$ & Remarks \\
\hline 1. & $\begin{array}{l}\text { I buy foods from canteens and eateries in } \\
\text { my neighborhood. }\end{array}$ & 3.72 & 0.62 & 3.54 & 0.88 & 1.21 & $\mathrm{~N} / \mathrm{S}$ \\
\hline 2. & $\begin{array}{l}\text { Neighborhood brings the market close to } \\
\text { my family. }\end{array}$ & 3.65 & 0.60 & 3.66 & 0.75 & 0.84 & $\mathrm{~N} / \mathrm{S}$ \\
\hline 3. & $\begin{array}{l}\text { I eat more when I eat with friends or } \\
\text { neighbor. }\end{array}$ & 3.85 & 0.58 & 3.70 & 0.64 & 0.61 & $\mathrm{~N} / \mathrm{S}$ \\
\hline 4. & $\begin{array}{l}\text { We buy food stuff available in my } \\
\text { neighborhood shops if going to market is } \\
\text { impossible. }\end{array}$ & 3.26 & 0.45 & 3.02 & 0.65 & 0.56 & $\mathrm{~N} / \mathrm{S}$ \\
\hline 5. & $\begin{array}{l}\text { I consume a lot of snacks and processed } \\
\text { foods sold in my locality. }\end{array}$ & 3.67 & 0.68 & 3.30 & 0.75 & 1.28 & $\mathrm{~N} / \mathrm{S}$ \\
\hline 6. & $\begin{array}{l}\text { Most convenience foods we eat are bought } \\
\text { in our neighborhood. }\end{array}$ & 3.02 & 0.45 & 3.17 & 0.60 & 0.72 & $\mathrm{~N} / \mathrm{S}$ \\
\hline 7. & $\begin{array}{l}\text { Neighborhood shops help us to consume } \\
\text { fresh fruits and vegetables }\end{array}$ & 2.02 & 0.50 & 3.04 & 0.68 & 3.18 & $\mathrm{~S}$ \\
\hline 8. & $\begin{array}{l}\text { At times Ijoin neighbors to eat their native } \\
\text { foods. }\end{array}$ & 3.03 & 0.82 & 3.06 & 0.55 & 1.46 & $\mathrm{~N} / \mathrm{S}$ \\
\hline
\end{tabular}




\begin{tabular}{|c|l|l|l|l|l|l|l|}
\hline 9. & $\begin{array}{l}\text { I enjoy eating with friends in the } \\
\text { neighborhood. }\end{array}$ & 3.02 & 0.78 & 3.00 & 0.77 & 1.15 & $\mathrm{~N} / \mathrm{S}$ \\
\hline 10. & $\begin{array}{l}\text { Most of the processed foods we consume } \\
\text { are from my neighborhood. }\end{array}$ & 3.44 & 0.65 & 3.00 & 0.75 & 0.62 & $\mathrm{~N} / \mathrm{S}$ \\
\hline
\end{tabular}

Key, $\bar{X}_{1}$ - urban respondent $\bar{X}_{2}$ - rural respondents $N=679, n_{1}=400$ and $n_{2}=279 . N / S=$ Not significant $=\mathrm{S}=$ Significant

Table 3: Shows that, all the respondents agreed with all the items as home environment factors affecting the eating behavior of the adolescent. All the mean scores were above the cutoff of 2.50. The standard deviation of the maternal factors items ranged from 0.45 to 0.88 Indicating that respondents were close in their opinion. The result also indicates that all the items had t calculated less than t-table value of 1.96 at .05 level of significant. Therefore, the hypothesis of significant difference between ratings of the respondents was retained.

Research Question 4. What are the media factors affecting the eating behavior of adolescent in Esan West Local Government Area.

Hypothesis 4: There is no significant difference between the responses of Urban and Rural adolescent on the media factors affecting the eating behavior of the adolescent.

Table 4: Mean and t-test of Responses of Urban and Rural Adolescent on Media Factors affecting Adolescent Eating Behavior in Esan West Local Government Area

\begin{tabular}{|l|l|l|l|l|l|l|l|}
\hline $\mathbf{S} / \mathbf{n}$ & Items & $\begin{array}{l}\mathbf{X}_{1} \\
\text { (urban) }\end{array}$ & $\mathbf{S D}_{1}$ & $\begin{array}{l}\mathbf{X}_{\mathbf{2}} \\
\text { (rural) }\end{array}$ & $\mathbf{S D}_{2}$ & $\begin{array}{l}\mathbf{T}- \\
\text { calt }\end{array}$ & Remarks \\
\hline 1 & $\begin{array}{l}\text { I leant some new foods from the media } \\
\text { advertisement }\end{array}$ & 3.28 & 0.96 & 2.88 & 0.50 & 1.01 & $\mathrm{~N} / \mathrm{S}$ \\
\hline 2 & $\begin{array}{l}\text { I like taking sugary drinks due to the } \\
\text { captivating advertisement }\end{array}$ & 3.33 & 0.84 & 3.08 & 0.83 & 0.88 & $\mathrm{~N} / \mathrm{S}$ \\
\hline 3 & $\begin{array}{l}\text { My fruits and vegetable intake has } \\
\text { increased due to media usage. }\end{array}$ & 1.04 & 0.98 & 1,01 & 0.97 & 0.71 & $\mathrm{~N} / \mathrm{S}$ \\
\hline 4 & $\begin{array}{l}\text { I practice some nutrition tips learnt from } \\
\text { the media }\end{array}$ & 3.20 & 0.96 & 2,70 & 0.91 & 0.76 & $\mathrm{~N} / \mathrm{S}$ \\
\hline 5 & $\begin{array}{l}\text { I prefer eating foods leant from the } \\
\text { media outside home. }\end{array}$ & 3.40 & 0.96 & 2.80 & 0.97 & 1.08 & $\mathrm{~N} / \mathrm{S}$ \\
\hline 6 & $\begin{array}{l}\text { Media usage has exposed me to all sorts } \\
\text { of drinks }\end{array}$ & 3.30 & 1.00 & 3.20 & 0.87 & 0.82 & $\mathrm{~N} / \mathrm{S}$ \\
\hline
\end{tabular}

Key, $\bar{X}_{1}-$ urban respondent $\bar{X}_{2}$ - rural respondents $N=679, n_{1}=400$ and $n_{2}=279 . N / S=$ Not significant $=\mathrm{S}=$ Significant.

Table 4: Shows that all the respondents agreed with all the items as media factors affecting the eating behavior of the adolescent. All the mean scores were above the cutoff of 2.50 . The standard deviation of the household factors items ranged from 0.50 that to 0.97 . This shows that the respondents were close in their opinion. The result also indicates that all the skill items had $t$ calculated less than t-table value of 1.96 at .05 level of significant. Therefore, the hypothesis of significant difference between ratings of the respondents was retained. 


\section{Discussion of Findings}

The findings from research question I, Table 1 reveal that respondents have poor eating behavior such as skipping of breakfast, low consumption of fruits and vegetable, low consumption of carbohydrates, consume sweets, biscuits, snacks, soda and sweetened drinks daily. These findings are in line with ${ }^{\mathbf{1 2}, 13}$ who opined that adolescents are not concerned with how diet can improve their lives, rather they engage in fact dieting in order to watch their weight in so doing, neglect the adequate diet they need. In addition, ${ }^{14}$ reported that skipping of breakfast is attributed with overweight, lack of vigor in the morning and decreased enthusiasm to do work. ${ }^{15}$ collaborated the finding by postulating that consumption of vegetables is less than three times in a week among adolescents, thus indicating poor food habits among Nigerian urban secondary school girls. This is found to be consistent with study of ${ }^{\mathbf{1 6}}$. Similarly, ${ }^{\mathbf{1 7}}$ posited that adolescents living in remote rural Scotland frequently consume vegetables and rarely consume sweets.

The result of hypothesis I also reveal that there were significant differences among the 3,5,6\&7of the eating behavior in favor of the rural respondents, this finding is in line with ${ }^{\mathbf{1 7}}$ who opined that young people living in the rural areas have a healthier diet than those living in urban areas in remote Scotland.

In response to research question 2, Table 2 indicates that respondents perceived that the 10 items are maternal factors affecting eating behavior of adolescent. This implies that respondents agreed that these items are mother related factors that is capable of having impact on the eating behavior of the adolescent either positively or negatively. This finding is in line with ${ }^{6}$ who asserted that maternal interest in healthful eating is certainly linked with adolescent fruit and vegetable consumption. In Nigeria, the mother's figure as it concerns nutrition is of paramount importance. Since she prepares the meals and encourages the children to eat by her exhibition in culinary skills. This is further supported by ${ }^{\mathbf{7}}$ and ${ }^{\mathbf{1 8}}$ who posited that parents have potential to influence children positively through family meals. Others include, maternal involvement in the rendering of nutrition education to family members, family having meals together, and parents spending time with the adolescent. Findings from table 2 also indicate that all the items had t calculated less than t-table value of 1.96 at .05 level of significant. This implies that mothers are the same everywhere having caring and loving characteristics to meet the needs of their children.

Table 3: Shows that all the respondents agreed with all the items as home environment factors affecting the eating behavior of the adolescent. All the mean scores were above the cutoff of 2.50. This implies that the respondents perceived that the items are household environmental factors capable of affecting food behavior of adolescent. This finding is in line with the assertion of 19 Who postulated that Healthy eating is the environment within which the selection and consumption takes place not only a factor of the nutritional quality of foods. Supporting this view, ${ }^{\mathbf{1 1}}$ posited that when certain foods are unavailable it results to decreased choice and intake. Corroborating these views, ${ }^{\mathbf{8}}$ stated that food availability in the environment has been an important context influencing the eating pattern and weight gain status among families. The result also indicates that all the skill items had $\mathrm{t}$ calculated less than t-table value. Consequently, the hypothesis of no significant difference between ratings of the respondents was retained in these items. 
Table 4 shows that all the respondents agreed with all the items as household media factors affecting the eating behavior of the adolescent. All the mean scores were above the cutoff of 2.50. This implies that the respondents perceived that the items are household media factors capable of affecting food behavior of adolescent. This finding is in line with ${ }^{20}$ Adolescent girls open to advertising were more expected to eat desserts, Source for new foods in supermarket and are more likely to make attempt to lose weight. Furthermore, supporting this finding is ${ }^{21}$ who opined that children who watch television will demand type of food in the commercial. The result also indicates that all the items had t calculated less than t-table value of 1.96 at .05 level of significant. Therefore, the hypothesis of significant difference between ratings of the respondents was retained.

\section{Implications for Home Economics}

The Senior Secondary School food and nutrition curriculum is encompassed with nutrition topics capable of teaching the students the ideal food behavior. Lately, very many schools in Esan West opted out of the programme by not enrolling students for the West Africa Examination Council, indicating that students and teachers are losing interest in the subject. This study showed that maternal, environmental and media are factors affecting the eating behavior of the adolescent, the school ought to be the appropriate place to teach good and proper eating behavior. The home is unable to inculcate such into the adolescent. Home Economics (Foods \&Nutrition) will help students to develop enduring eating behavior capable of sustaining them and also helping them to avoid the non-communicable diseases later in life. Therefore, Home economics should be revitalized in the various levels of education to provide opportunities for students to learn the true principles and practice of nutrition and not the fallacies and fables from home, environment and the media.

\section{Conclusions and Recommendations}

It is of paramount importance to note that the eating behavior formed during the adolescent period will span through adulthood. The non-communicable diseases are on the increase and eating behavior is one of the associated factors. The study showed maternal, environmental and media factors affecting the eating behavior of the adolescents. This implies that, changes in the current figure on the death rate as a result of no-communicable diseases can be reduced if eating behavior are well managed. As it well known, the most important indicator of health is a child's growth which is prejudiced by adequate intakes of food and nutrients. Adolescent poor eating behavior may result to chronic conditions in adulthood and prevention is crucial. Therefore, the following were recommended:

1) Awareness campaign should be organized by government and nongovernmental organizations to teach parents the importance of acquiring nutrition knowledge to improve their children's eating behavior.

2) Parents should be advised to guide and monitor their children in the use of the media, by occupying their children with other physical activities to reduce television viewing, video games and the use of computer, so as to guide against the acquisition of wrong nutrition information that can lead to poor eating behavior. 


\section{References}

[1] Onumah,O,A \&Asinobi C.O (2007). Nutritional Assesement of Adolescent School Children at Growth Developmental Stages in Owerri Municipality. Nigeria Journal of Nutrtional Scs.Vol 28(2) 128-140.

[2] Brasel, J. (1982). Changes in body composition during Adolescence. In: Adolescent Nutrition. Winich M (ed). John Wiley and Sons, New York.

[3] Lai Yeung, W,T (2010) Gender Perspectives on Adolescents Eating Behaviours; Astudy on Eating Attitudes and Behaviours of Junior Secondary Schools in Houng Kong.Jounal of Nutrition Education and Behaviour 42(4)251-257.

[4] Eleanor, R G., Nanette I,S., (2011) Genetics of Eating Behaviour: Established and Emerging Concepts .Nutrition Review69(1):52-60

[5] Birch, L., Savage, J.S., Ventura, A. (2007). Influences on the Development of Children's Eating Behavior from Infancy to Adolescence. Can J. Diet Prac Res 38(1) $1-56$.

[6] Boutelle K.N, Birkel RW, Hannan P.J, Story M,\& Neumark-Sztainer P. (2007). Association between maternal concern for Healthful eating and maternal eating behaviors, home foor availability and adolescent eating behavior. J. Nutrition Educational Behav. 39(5) 248 - 256.

[7] Michelle M.S, Georguanna M, Elena, L.S. Alisha, R.F (2017). Parenting Practice toward Food and Children's behavior: eating away from home versus home. Appetite Vol 114, Pg $194-199$.

[8] Powel L.M, Chaloupka F.J, Auld, O’Malley P.M, Johnston L.D. (2007). Association between access to food stores and Adolescent body mass indiex. Am journal Prev. Med. 33 (4 supplementary) $301-307$.

[9] Dangevos, H, Munnichs, G. (2007). De OsesogeneSamenleving: maatschapelykeperspection op overweight. Amsterdam: Amsterdam University Press.

[10] Meiselman, H. (2006). The Impact of context and Environment on consumer food choice. In:

[11] Browell, K.D\&Horgen,K.B(2004) Food Fight The Iside Story of the Food Industry Americans Obesity Crisisand What We can DoAbout it.Chicago ComtemporaryBooks. http://cmc marhiot.org.Retrieved 18/10/2018

[12] Jeanette, S.A. (2003). Medical Nutrition Therapy for Liver Bilary System and Exocrine Pancrease Disorder. Washington DC USA. National Academic Press.

[13] Okafor P. (2011). Factors Influencing students consumption of fruits and vegetables in University of Benin, Nigeria. An Unpublished M.Ed Project submitted to Vocational and Technical Education, University of Benin, Benin City.

[14] Hean M.D, Baranowski, T, Baranowski J. Doyle C., Smith M.\& Lin L.S, (1998). Environmental influences on Dietary behavior among children: availability and Accessibility of fruit and Vegetable enable Consumption. Journal of Health Education Vol. 29 pg $26-32$.

[15] Onyeruka A.N, Ibeawuchi A.N., Ibeawuchi A.N.\& Onyiruka R.C. (2013). Assessment of eating habits among adolescent Nigerian Urban Secondary School girms. Sri Lanka Journal of Child Health. 42(1) $20-26$.

[16] Olumakaiye M.F, Atimo,A. Olubayo-Fatiregun (2010). Food consumption Patterns of Nigerian Adolescents and Effect on Body Weight. Journal of Nutrition Education and Behavior, Vol. 47(3) 144-151.

[17] Levin K.A. (2014). Urban - rural difference sin Adolescent eating behavior: a multi level crosssectional study of 15-year olds in Scotland Public Health Nutrition 17(8) 1776 - 85.

[18] Fitzgerald A., Heary C. Kelly C \& Nixon E. (2009) Factors Influencing the food Consumption of Children and Adolescents: a quantitative investigation. Proceedings of the Nutrition society 67 (OCE 7) E226, 18 - 20.

[19] Neeley, S.M. (2011). The influence of school Eating Environment on Children's Eating behaviors: An Examination of the SN DA - 111 Wright State University, Dayton, Ohio. http://corescholar.libranes.wright.edu/mph.Retrieved 17/10/2018 
[20] Elham, A (2016) The Impact of Media and Advertising of Food on the Eating Behavior of Adolescent Girls in Jeddah, Saudi Arabia Eastern Mediterranean Health Journal 22(9);662-667

[21] Lopez,J (2014), The Influence of Media on our Food Choices .your health journal. com. Retrieved on $22 / 10 / 20018$

*Corresponding author.

E-mail address: ineose05@yahoo.com 